\title{
Simultaneous breast reconstruction with transverse rectus abdominal myocutaneous (TRAM) flaps
}

\author{
SV Sidorov MD, KV Vardosanidze MD, SP Shevchenko MD \\ Medical Institute, Novosibirsk/Hospital \#25, Novosibirsk, Russia
}

\section{SV Sidorov, KV Vardosanidze, SP Shevchenko. Simultaneous breast reconstruction with transverse rectus abdominal myocutaneous (TRAM) flaps. Can J Plast Surg 1998;6(3):146-148.}

\begin{abstract}
Breast reconstruction with transverse rectus abdominal myocutaneous (TRAM) flaps on pedicles was performed simultaneously with radical mastectomy in 73 patients with breast cancer. In the case of the tumour exceeding the breast borders, or edemo-infiltrative form of cancer, radical mastectomy was accomplished, and the wound defect on the chest wall was closed without technical difficulties, while simultaneously solving the aesthetic part of the operation. Complications were noted in 13 patients (17.8\%), and with revision, complications were eliminated without impairing cosmetic effect. Recurrence of the breast cancer was noted in $9.6 \%$ of patients, which is explained by the presence of hidden separate metastases not located during the preoperational period or operation. An individual approach in solving the task of simultaneous breast reconstruction with radical mastectomy is necessary in each patient.
\end{abstract}

Key Words: Breast reconstruction, Transverse rectus abdominal myocutaneous (TRAM) flaps

\section{Reconstruction mammaire simultanée avec lambeaux myocutanés du grand droit abdominal}

RÉSUMÉ : La reconstruction mammaire au moyen de lambeaux myocutanés du grand droit abdominal à partir des pédicules a été effectuée simultanément avec mastectomie radicale chez 73 patientes atteintes d'un cancer du sein. Dans le cas de la tumeur excédant les rebords mammaires ou de formes cancéreuses œdémo-infiltratives, la mastectomie radicale a été effectuée et le défaut de la paroi thoracique a été refermé sans difficulté technique, tout en résolvant l'aspect esthétique de la chirurgie. Des complications ont été notées chez 13 patientes $(17,8 \%)$ et avec révision, les complications ont été éliminées, sans altérer l'effet esthétique. La récurrence de cancer du sein a été signalée chez 9,6\% des patientes, en raison de la prévalence de métastases distinctes cachées et non identifiées durant la période préopératoire ou durant l'opération. Une approche individualisée est nécessaire lorsque l'on veut procéder à une reconstruction mammaire simultanée avec mastectomie radicale.

B reast cancer is the number one oncological disease in many developed countries. About 540,000 newly revealed cases of breast cancer are annually registered all over the world (1). The highest number of cases occurs in those between 40 and 50 years old, when the importance of physical appearance increases.

Correspondence: Dr SV Sidorov, Novosibirsk-65, 2 Krasnodonskii per 7-43, 630104, Russia. Telephone 007-383-276-2229, fax 007-383-220-9405
Radical mastectomy remains a basic treatment of patients with breast cancer. It harshly damages women's psychoemotional sphere; most patients are ashamed of the physical change after operation, considering themselves less attractive (2); approximately $24 \%$ quit their job because of rehabilitation difficulties (3); and about $10 \%$ experience fear of change in social acceptance (4).

Many oncologists perform conservative operations on the local forms of breast cancer if they do not exceed 2.5 to $3 \mathrm{~cm}$ 
$(5,6)$. However, multicentric growth of cancer occurs in up to $20 \%$ of cases (7) and neoplastic invasion of nipple in $70 \%$ of cases (8). Involvement of the nipple-areolar complex in the case of tumour dimension $\mathrm{T} 1$ is noted in $2 \%$ of patients, $\mathrm{T} 2 \mathrm{in}$ $4 \%$ and $\mathrm{T} 3$ in $15 \%$ (9). Local recurrences of $\mathrm{T} 1$ occur in $7 \%$ of patients and of T2 in 10\% (10), which explains why some oncologists seek to perform radical mastectomy even in the case of small breast cancer $(11,12)$.

In the case of large tumours, treatment remains radical mastectomy, which leads to negative changes in psychological status of patients due to resulting physical change. Full rehabilitation of patients after mastectomy is impossible without breast reconstruction. Factors for the reconstructive operation are set for each individual $(13,14)$.

\section{PATIENTS AND METHODS}

From 1992 to 1996, 78 radical mastectomy operations were performed at the authors' institution with simultaneous breast reconstruction using transverse rectus abdominal myocutaneous (TRAM) flaps. Mean age of patients was 38.2 years (range 22 to 56 ).

The distribution according to the stage of cancer development was as follows: T1N0M0, four patients; T2N0M0, 15; T2N1M0, eight; T3N0M0, eight; T2N2M0, five; T3N2M0, eight; and T4N1-2M0, 15. A special group comprised patients with an edemo-infiltrative form of cancer $(n=8)$ and with the tumour exceeding the breast borders $(n=7)$.

Treatment was solely surgical in eight patients; radiation therapy and surgery in 11; and radiation therapy, surgery and chemotherapy (and/or hormonal therapy) in 54. For radical mastectomy, Halsted's modification was used in eight patients, Patey's modification in 39 and Madden's modification in 26. For breast reconstruction, the upper TRAM flap was used in 12 patients and the lower TRAM flap in 61.

The authors consider previous genital operations and postoperative scars in the regions of the rectus abdominus muscles below the navel as indications for the upper TRAM flap. To achieve a larger area of the breast being reconstructed, mobilization of the TRAM flap was performed on two rectus abdominus muscles $(\mathrm{n}=5)$. In small breast mobilization, the TRAM flap was performed on one rectus abdominus muscle ( $\mathrm{n}=7$ ).

The authors consider reconstruction of medium and large breasts, absence of postoperative scars below the navel and hyperstenic type of constitution as indications for the lower TRAM flap. In the case of the well-developed rectus abdominus muscle, the TRAM flap is mobilized on one rectus abdominus muscle $(n=36)$. In the case of weak muscles, small diameter of arteria epigastria inferior and patients who smoke, the TRAM flap is mobilized on two rectus abdominus muscles $(n=25)$.

Radical mastectomy with simultaneous breast reconstruction was performed simultaneously by two surgical teams. Mean operation length was $3 \mathrm{~h}, 34$ mins (range $2 \mathrm{~h}, 15$ mins to $4 \mathrm{~h}, 3$ mins). Defect of aponeurosis of the rectus abdominus muscles was closed by the local tissues in 37 patients and by the vascular dacron prothesis in 36 . Blood loss during the operation was recovered using red cell mass (average quantity $228 \mathrm{~mL}$ ) and plasma transfusion (average quantity $204 \mathrm{~mL}$ ). Active aspiration of the wound lymphuria was performed after five to seven days. Walking activity was allowed after four to five days.

During the first stage of breast reconstruction, complications were noted in 13 patients (17.8\%), suppurative and necrotic complications in $11(15.1 \%)$ and relaxation of the abdominal wall in two (2.7\%). All these patients had revisional surgery from which no complications were noted.

During the second stage of breast reconstruction (no less than three months after the primary breast reconstruction), reconstruction of the nipple-areolar complex was performed in 41 patients, and in two patients, cosmetic changes were done to the healthy breast. No complications in these 43 patients were noted.

In a 34-year-old patient with synchronic cancer in both breasts, double radical mastectomy with simultaneous breast reconstruction using the split lower TRAM flap was performed with a good cosmetic effect.

The progress of cancer metastases in the distant organs was later noted in seven patients $(9.6 \%)$. No local recurrences were noted. Four patients $(5.5 \%)$ died from breast cancer. Three patients currently receive chemotherapy and hormonal therapy.

\section{DISCUSSION}

Simultaneous breast reconstruction after radical mastectomy proves to be an integral part of rehabilitation for breast cancer patients. Using patient's tissues for simultaneous breast reconstruction can be achieved in two ways: reconstruction with free TRAM flaps and reconstruction with TRAM pedicle flaps.

In the case of the tumour exceeding the breast borders the edemo-infiltrative form of cancer - the problem of closing the wide wound defect on the chest wall is successfully solved using TRAM pedicle flaps (15-17). We encountered and solved this problem in 13 patients.

During the first phase of breast reconstruction it is not necessary to achieve full symmetry of the breasts; this is easily accomplished during the second stage.

We advocate simultaneous breast reconstruction using TRAM pedicle flaps.

\section{REFERENCES}

1. Aubry C, Deschamps J. Depistage du cancer du sein par l'auto-examen. Concours Med 1990;5:434-7.

2. Margolis G, Goodman RL, Rubin A. Psychological effects of breast-conserving cancer treatment and mastectomy. Psychosomatics 1990;31:33-9.

3. Gairard B, Schranz B, Guldenfels C, Renaud R. Qualite de vie et traitements du cancer du sein. Progr pathol mammaire. J Soc Fr Senol Pathol Mamaire 1989:261-70.

4. Zemore R, Rinholm J, Shepel LF, Richards M. Some social and emotional consequences of breast cancer and mastectomy: A content analysis of 87 interviews. J Psychosoc Oncol 1987;7:33-45.

5. Kappes-Grande I. Guerir en conservant le sein. Comprendre Agir 1990;14:16-9. 
6. Veronezi U, Bolterrani F, Luini A, Saccori R, Salvadori B. Quadrantectomy versus lumpectomy for small size breast cancer. Eur J Cancer 1990;26:671-3.

7. Hoffman E. The contralateral breast in ipsilateral breast carcinoma. South Med J 1990;83:1009-15.

8. Spinelli C, Berti P, Ricci E, Lacconi P, Miccoli P. Sgnificato prognostico dell'infiltrazione microscopica del cappezzolo nel carcinoma della mammella. G Stal Senol 1990;11:35-8.

9. Santini D, Jaffukelli M, Carolona GM, et al. Neoplastic involvement of nipple-arealar complex in invasive breast cancer. Am J Surg 1989;158:399-403.

10. Pierquin B, Mazeron JJ, Glanbinger D. Conservative treatment of breast cancer in Europe: Report of the Group European de Curientherapie. Radiother Oncol 1986;6:187-98.

11. Cervi GC, Guilni SM, Pouche A, et al. La multicentricita del cancero minimo della mammella: Osservazioni e implicazioni terapeutiche a proposito di 30 casi. Minerva Med 1989;80:895-9.

12. Enomoto K, Ikeda T, Abe O. [Controversy on the treatment of early breast cancer]. Gan No Rinsho 1984;30:624-9.

13. Filiberty A, Rimoldi A, Callegari M, et al. Immediate versus delayed breast reconstruction. Eur J Plast Surg 1990;13:55-8.

14. Ward CM. Delayed reconstruction of the breast after mastectomy. Ann R Coll Surg Engl 1989;71:182-6.

15. Babayan R. Reconstruktion der Mamma nach Amputation mit myokutanem insellappen bom M. rectus abdominis. Med Welt 1986;37:610-3.

16. Bostwick J, Paletta C, Hartrampf CR. Conservative treatment for breast cancer. Complications requiring reconstructive surgery. Ann Surg 1986;203:481-9.

17. Sorrentino P, Baccaglini U, Castoro C, et al. L'uso del lembo miiocutaneo di gran dorsale nel carcinoma mammario localmente avanzato. G Chir 1989;10:670-3. 